\title{
ILMU SOSIAL TRANSFORMATIF
}

\author{
Purwo Santoso \\ Fakultas Ilmu Sosial dan Ilmu Politik Universitas Gadjah Mada, \\ Email: psantoso.fisipol@gmail.com.
}

\begin{abstract}
Social science which is intended in this paper covers a variety of disciplines, including sociology, political science, economics, anthropology, bistory, law and so on. The term transformative in the sense used bere ane loose, just to indicate bow the scientists ane not only struggling to answer the questions themselves, but the botber and in turm devote bis dedication to the community to answer questions. Development of a transformative social science requines expertise in three-dimensional philosopby of science: the ontology, epistemology and aciology. Transformative character is also determined by the choice aksiologisnya. Social sciences were developed not only for dewelopment or accumulation of theory but also to improve the sociai relations that existed, to produce a social reality which was considered better.
\end{abstract}

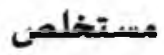

العلوم الاجتماعية الذي يهدف في هذه الورقة تغطي مجهـوعة هتنوءهلة من التَخصصات، بما في ذللـ، العلم، وءام الاجتماع السياسي، والاقتصاد، والأنثروبولوجيا والتاريخ والمانون وهلم جرا.

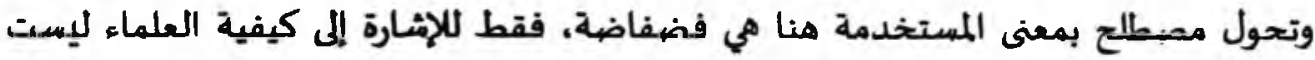
فقط تكافح من أجل الإجابة على الأسئلة نفسها، ولكن عناءء وبالتالي تكربس تفاتيه في المجتمع

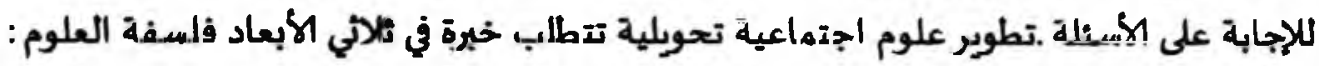
علم الوجود، ونظورة المعرفة يتم تعديد شيخصبية تعولية من قبل الاختيار .وقد وضعت العلوم الاجتماعية اليس فقط من أجل تطوير أو تراكم من الناحية النظربة وإكن أيضا من أجل

- Artikel ini merupakan versi revisi dari Pidato Pengukuhan Jabatan Guru Besar Pada Fakultas Dmu Sosial dan Ilmu Politik Universitas Gadjah Mada Diucapkan di depan Rapat Senat Terbuka Universitas Gadjah Mada Pada tanggal 18 April 2011di Yogyakarta. 
تحسين العلاقات الاجتماعية التي كانت مونودةة، لإنتاج الواقع الاجتمائي الذي كان بعتبر أفضمل.

Keywords: Ilmu Sosial, Transformatif, Islam, Humanis

\section{A. Pendahuluan}

Obsesi go internasional universitas-universitas di Indonesia, seperti Universitas Gadjah Mada, bagaimana pun, obsesi go international jangan sampai melupakan esensi universitas itu sendiri, yakni "untuk pengembangan ilmu". Perlu diingat bahwa kebijakan go international selama ini berlangsung bersamaan dengan semakin meluasnya kesadaran bahwa ilmu sosial di negeri ini sedang mengalami krisis jati diri. Dalam situasi ini, ilmuwan sosial diajak untuk tampil dalam bingkai World Class Research University (WCRU). Agar tidak terbuai dengan label world class, para ilmuwan sosial harus memikirkan ilmu sosial yang betulbetul berkarakter. Jawaban atas persoalan di atas adalah: ilmu sosial yang transformatif. Atas dasar itulah, fulisan ini berjudul "Ilmu Sosial Transformatif".

\section{B.Ilmu Sosial Netral?}

Sudah menjadi tahasia umum bahwa ilmu pengetahuan adalah alat kekuasaan. Pengembangan ilmu dalam skala intemasional tentu saja berlangsung dalam peta kekuatan dan kekuasaan internasional juga. Dari pendapat sederhana ini cukuplah alasan untuk mengatakan bahwa jerih payah bersama dalam pengembangan ilmu, termasuk ilmu-ilmu sosial, tidak mungkin bersifat netral.

Sungguhpun demikian, kegiatan pengembangan ilmu, termasuk pemaparan diri dalam skala internasional melalui obsesi WCRU, lazim dilakukan di bawah asumsi adanya ilmu sosial yang netral, termasuk netral dari kepentingan politik dan ekonomi intemasional. Teori-teori sosial diasumsikan bersifat netral sehingga memberikan penjelasan yang "apa adanya", dan bukan sebaliknya "ada apanya". 
Dalam cara pandang yang populer, teori-teori sosial diperlakukan sebagai kebenaran dan fakta universal. Di Indonesia, penerapannya ke dalam kehidupan masyarakat dipahami sebagai aktivitas keilmuan belaka. Padahal, penerapan teori ke dalam kehidupan masyarakat adalah suatu pertaruhan nasib. Tidaklah mengherankan jika penerapan paket-paket teori impor, apalagi yang belum sempat dikaji-sesuaikan dengan kondisi negeri ini memunculkan sejumlah persoalan baru.'

Tanda-tanda ini memang terasa klasik dan romantis. Bahkan banyak ilmuwan menepisnya dengan mengatakan: ilmu sebarusnya tidak dibatasi oleh nasionalisme. Terhadap tepisan ini kita perlu mencermati bahwa ilmu sosial di negeri ini adalah ilmu tentang kita. Teori-teori yang dibangun orang asing tentang kebersamaan kita merupakan ketidaksadaran kita akan arti penting masa depan kita sendiri. Pengetahuan orang asing tentang kita pada dasarnya adalah kesempatan lebih pada mereka untuk menguasai kita. Penguasaan akan ketidaksadaran kita adalah pintu penjajahan ataupun dominasi. Apa yang terjadi kalau kendali pengembangan ilmu tidak ada pada diri kita? Kctidaksadaran tentang keseharian kita yang secara diam-diam telah mereka teorisasikan, memungkinkan mereka mengendalikan diri kita melalui ilmu pengetahuan.

\section{Problema Kolektif}

Ada yang mengatakan di negeri ini ilmu mengalami kemandegan, dan ada juga yang menilai terlilit krisis. ${ }^{2}$ Pertandanya antara lain mengatakan bahwa

1 Sekedar menyebut contoh, para ilmuwan begitu lantang mengatakan Indonesia adalah negara hukum, namun pemberitaan media massa membukakan mata kita bahwa hukum tidak kunjung dapat ditegakkan. Teori-teori demokrasi begitu fasih dilafalkan para ahli, namun demokratisasi yang mereka gagas tidak kunjung selesai. Begitu juga dengan reformasi birokrasi. Cukuplah bukti awal untuk curiga bahwa krisis yang dirasakan bangsa ini ada hubungannya, kalau tidak disebabkan oleh, krisis keilmuan yang tidak dengan mudah dirasakan para ilmuwan Indonesia sendiri.

2 Untuk memperingati hari jadi-nya yang ke 47, Fakultas Ilmu Sosial dan Ilmu PolitikFISIPOL UGM mengadakan sebuah seminar yang secara spesifik membahas state of the art ilmuilmu yang diampu di Fakultas ini. Untuk mencermati ide-ide yang dibahas dalam konferensi tersebut lihat Purwo Santoso, "Potret Politik Ilmu-ilmu Sosial: Di Ambang Involusi", paper yang direpresentasikan dalam Seminar Nasional peringatan HUT ke-47 Fakultas Ilmu Sosial dan Politik, Universitas Gadjah Mada, 25 September 2002. Pada tahun 2005, FISIPOL UGM 
kontribusi para ilmuwan sosial dalam pengembangan ilmu, baik pada tataran teoritik maupun metodologis, belum bisa dibanggakan. ${ }^{3}$ Selain itu ilmuwan sosial negeri ini masih terkesan bingung menentukan posisi di antara sekian banyak aliran atau mazhab para teoritikus asing. Misalnya, perdebatan tentang politik dan pemerintahan di Indonesia, acuan populer yang acapkali digunakan sebagai rujukan adalah hasil kajian para Indonesianis non-Indonesia. ${ }^{4}$ Padahal ada ilmuwan negeri ini yang mampu mengkaji lebih baik, hanya saja dinilai tidak setara dan tidak spektakuler.

Yang jelas, Indonesia telah lama diperankan sebagai lokasi penelitian para ilmuwan sosial mancanegara. Dalam kurun waktu yang cukup lama, sepertinya kita hanya membiarkan hal itu terus' terjadi. Bahkan dari penelitian-penelitian mereka boleh dibilang telah melahirkan teori-teori besar. Ada teori dual society yang dirumuskan Booke ${ }^{5}$, teori politik aliran yang ditawarkan Hierbert Feith dan Lance Castle, ada teori tentang kekuasaan dalam masyarakat Jawa yang ditawarkan oleh Benedic Anderson ${ }^{7}$ dan entah apa lagi. ${ }^{8}$

menggelar even serupa dan membahas isu yang sama. Nada pesimistis masih tetap terdengar. Sebagian makalah yang dipresentasikan dimuat dalam Jurnal Ilmu Sosial dan Ilmu Politik, Vol. 9, No. 2, November 2005.

3 Purwo Santoso; "Defisiensi Teori Pemerintahan: Refleksi Atas Desentralisasi di Indonesia", Paper dipresentasikan dalam Seminar Internasional XI Dinamika Politik Lokal di Indonesia: Adz Apa Dengan 10 Tahun Otonomi Daerah, Salatiga, 21-23 July, 2010.

${ }^{4}$ Sebagai mantan redaktur Jumal Sosial of Politik di FISIPOL UGM saya juga merasakan sendiri betapa tidak mudah mendapatkan naskah untuk dipublikasikan

${ }^{5}$ J.H. Boeke, Economics and Economic Policy of Dual Soeriety, Tjeenk Willink \& Zoon, Haalem, 1953. J.H. Boeke, "Three Form of Disintegration in Dual Societies", Indonesie, Vol. 7, No.4, April 1954. Juga, J.H. Boeke, "Western Influence on the Growth of Eastem Population", Economia Intermationale, Vol. 7, No, 2, 1954.

6 Herbert Feith, Lance Castles (eds.), Indonesian Political Tbinking 1945-1965, Equinox Publishing, 2007.

${ }^{7}$ Benedic RO'G Anderson, "The Idea of Power in Javanese Culture", dalam Claire Holt (ed.), Culture and Politics in Indonesia, First Equinox Edition, 2007.

${ }^{8}$ Memang, para ilmuwan Indonesia ikut berjasa dalam melahirkan teori-tersebut, namun perannya adalah sebagai nara sumber dalam pengumpulan data kalau bukan sebagai asisten peneliti. Dalam pengembangan teori-teori tersebut ilmuan Indonesia biasanya tidak menjadi arsitek yang merancangnya. Yang ilmuwan sosial di negeri ini getol memanfaatnya, menjadikannya sebagai rujukan. 
Universitas memiliki kapasitas untuk mengembangkan ilmu, praktis melekat tanggung jawab moral kapasitas belajar dari komunitas keilmuan di dalamnya. Yang diperlukan bukan hanya pembelajaran pada diri masing-masing ilmuwan, namun juga komunitas ilmuwan secara keseluruhan. ${ }^{9}$ Pada level inilah universitas di negeri ini masih bermasalah. ${ }^{10}$ Boleh jadi komunitas ilmuwan sosial di negeri ini mengalami sindrom collective leaming difficulty (kesulitan belajar dalam kebersamaan), kalau bukan collective leaming dissability (ketidakmampuan belajar dalam kebersamaan). Universitas bisa saja menghasilkan sarjana, master, tenaga-tenaga profesional dan dokter yang baik, namun belum tentu memiliki kemampuan atau kecanggihan dalam hal pembelajaran (leaming) untuk menghasilkan temuan-temuan baru.

Jika pengembangan ilmu tidak disertai dengan visi "politik" keilmuan yang jelas, peranan ilmuwan sebetulnya hanyalah sekedar sebagai partisipan dari suatu sistem informasi." Oleh sebab itu, studi Carlile tentang sistem informasi yang dilakukan dalam hubungan antarbangsa mengidentifikasi adanya tiga derajat leaming organization jika di lihat dari kemampuan belajarnya: (1) sintaktis, (2) semantik dan (3) transformatif. ${ }^{12} \cdot$ Ketiganya dapat dijelaskan sebagai berikut:

9 Sehubungan dengan hal itu, UNESCO mengembangkan gagasan learning society. Dalam studi kebijakan dikembangkan gagasan epistemic community. Dalam studi Organisasi juga dikenal konsep learning organization and organizational learning.

10 Dalam keterbatasan yang ada pada diri saya, sejauh ini studi secara seksama tentang hal tersebut belum pernah dilakukan oleh ilmuwan sosial sendiri. Dalam kekosongan studi, ijinkanlah saya mengemukakan sejumlah indikasi awal, bahwa permasalahannya ada pada level kolektiktifitas. Percakapan secara sporadis dengan sejumlah doktor dan prosefor Indonesia yang bekerja pada sejumlah universitas di Malaysia menunjukkan bahwa ilmuwan sosial asal Indonesia memiliki kompetensi keilmuan yang lebih menonjol, meskipun mereka tidak terlihat menonjol ketika bekerja di negerinya sendiri. Atas dasar indikasi awal ini, cukup alasan untuk menduga bahwa hambatan belajar yang serius ada pada level kolektif.

11 Pengembangan ilmu tereduksi sekedar sebagai (1) akuisisi informasi, (2) distribusikan informasi, dan (3) penafsirkan informasi; serta (4) pengembangan memori organisasi. Lihat Huber, George P., "Onganizational Learning: The Contributing Process and the Literature", Orgnization Science, Vol. 2, No. 1 February 1991.

12 Carlile, Paul R., "Transferring, Translating, and Transforming: An Integrative Framewotk for Managing Knowledge across Boundaries," Organization Science, Vol. 15, No. 5 (Sep. - Oct, 2004), hal 555-568. 
Dalam derajat sintaktis, yang menjadi perhatian adalah ketepatan dalam menyampaikan informasi, yaitu transfer ilmu dan pemrosesan informasi secara apa adanya. Komunitas yang terlibat dalam pembelajaran tidak hirau persoalan metodologis. Belajar pada dasamya adalah meniru dan meniru. Dalam terminologi filsafat ilmu, obsesi mereka adalah penguasaan aspek ontologis dari pengetahuan yang digelutinya.

Tataran semantik lebih berani menafsirkan atau memahami makna tersirat di balik fenomena tertentu. Dalam aktivitas pembelajaran, proses menafsirkan tersebut mengandung resiko kabur atau bahkan salah, namun berpotensi menghasilkan pengetahuan baru berkat kepiawaian metodologi keilmuan. ${ }^{13}$

Pembelajaran transformatif ditandai oleh kemampuan mengambil manfaat berdasarkan kebutuhan yang jelas dan pada saat yang sama paham, fasih dalam menghayati dan menerapkan metodologi yang tersedia. Rerangkat dari kesadaran konteks dan pemahaman akan berbagai peluang yang terbuka, mereka terus menerus terlibat dalam memajukan pengetahuan untuk menjawab permasalahan dalam konteks yang berbeda.

Untuk itu kita perlu bertanya pada diri sendiri, tepatnya melakukan evaluasi diri dalam komunitas masing-masing; masuk kategori manakah model pembelajaran yang kita selenggarakan? Bilamana kita tampil dalam peringkat tinggi sebagai $W C R U$, namun model pembelajarannya ternyata berwatak sintaktik, maka peringkat yang tinggi tersebut sebetulnya sia-sia. Peranan kita, boleh di bilang, sekedar meniru-niru apa yang dilakukan oleh ilmuwan di tempat lain. ${ }^{14}$

${ }^{13}$ Jika dibandingkan dengan kalangan yang model belajamya semantik, yang kalangan yang mengembangkan pembelajaran semantik ini tidak terombang-ambing oleh perubahan, dan tidak panik dalam mensikapi kontroversi katena kokohnya pijakan epistemologisnya. Hanya saja, mereka tidak punya agenda yang jelas tentang apa yang harus dipelajari. Pengembangan pengetahuannya didiktekan oleh pasokan pengetahuan yang telah tersedia dalam literatur keilmuan.

14 Patutlah kita bersyukur sekiranya model pembelajaran dalam komunitas keilmuan kita berwatak semantik. Dengan modei pembelajaran seperti ini ilmuwan bisa mendudukkan persoalan sesuai dengan setting yang melingkupinya. Hanya saja, posisinya masih rawan disiasati oleh ilmuwan dari negara lain. Mengapa? Komunitas keilmuan yang ada bersifat melakukan kontektualisasi dari teori-teori yang dikembangkan oleh ilmuwan dari negara lain, namun bukan yang menjadi penemu dan penentunya. Dengan model pembejalaran seperti ini, mereka 
Jika sindrom kesulitan mengembangkan kemampuan belajar bersama memang menjangkiti komunitas keilmuan sosial di negeri ini, maka agenda pengembangan $W C R U$ menghadapkan kita pada situasi sulit. WCRU mengharuskan adanya manajemen resiko. Selain itu, keterlibatan dalam WCRU mensyaratkan dedikasi universitas untuk tetap berkiprah dalam pengembangan ilmu, bukan pengembangan peringkat. Jika keberhasilan naik peringkat ini tidak diikuti dengan peningkatan kemampuan mengembangkan ilmu, maka keterlibatan kita di level internasional tereduksi sebagai pematuhan terhadap arahan orang lain. Salah-salah kita terombang-ambing oleh perubahan global. ${ }^{15}$

\section{Politik Keilmuan}

Pelajaran yang bisa di petik dari pemaparan di atas adalah bahwa politik pengembangan ilma sangat memerlukan, namun tidak tidak bisa digantikan,

memang tidak ketinggalan, hanya saja tidak menjadi rujukan dan trend setter meskipun peringkatnya tinggi. Sebaliknya, arah pengembangan ilmu didiktekan oleh trend yang berkembang. Apa yang dianggap penting atau vital sangat tergantung dari trend tersebut. Model pembelajaran transformatiflah yang memungkinkan kita mengembangkan nasionalisme pengembangan ilmu sosial. Dengan model inilah ilmuwan di Indonesia ambil bagian dalam mexujudkan amanah konstitusi: mencerdaskan kehidupan bangsa. Pengembangan ilmu sosial didedikasikan untuk menjawab masalah-masalah bangsa, dan pengembangan ilmu tersebut disertai dengar menggembleng sarjama, master dan doktor yang sanggup memecahkan sebagian masalah barigsa ini dengan ilmu yang diasahnya. Yang jelas, untuk bisa keluar atau terbebas dari krisis keilmuan, komunitas ilmuwan dituntut untuk melembagakan proses pembelajaran transformatif. Sedangkan kapasitas untuk melakukan transformasi ditentukan oleh penghayatan falsafati ilmu yang ditekuninya. Yang tidak boleh dilupakan, penghayatan falsafah keilmuan ini dijabarkan dalam praktek sehari-hari dalam komunitasnya.

${ }^{15}$ Sebagai contoh sosial di Indonesia sangat asyik mengusung wacana yang sangat populer di era global, yakni wacana governance. Tidak sedikit dari pewacanaan tersebut melupakan telaah politik-ekonomi internasional yang memperlihatkan bahwa peredaran wacana tersebut adalah bagian tak terpisahkan dari liberalisasi. Antusiasme untuk merepoduksi wacana akhimya begitu menjadi-jadi sehingga para ilmuan ini tidak sadar bahwa yang dilakukan adalah bagian dari proses peminggiran peran negara dalam mengelola kepentingan publik. Kealphaan menyadari liberalisme adalah faham yang skeptis terhadap peran negara, yang seiring dengan kealphaan bahwa konsep governance yang diusungnya adalah varian liberal menjadikan sejumlah ilmuwan bukan hanya menjadi kaki tangan yang tidak sadar tujuan alias terombang-ambing. Apalagi, nafas liberal tersebut disembunyikan predikat 'good' bagi konsep govemance. Dalam konteks ini, ilmuwan sosial lebih berperan sebagai sales konsep yang berlaku pada tataran internasional dari pada perumus konsep untuk diterapkan dalam kompleksitas konteks sosio-kultural Indonesia. 
oleh pengembangan manajemen dan kelembagaan. ${ }^{16}$ Pengembangan ilmu tentu saja berdinamika, namun tidak boleh luput dari perhatian para ilmuwan itu sendiri. Obsesi untuk tampil sebagai WCRU perlu dilandasi dengan kalkulasi politik keilmuan antar negara.

Sehubungan dengan usulan untuk merumuskan politik ilmu tersebut di atas, dapat juga dikatakan tidak mudah karena tantangan pengembangan ilmu sosial sebetulnya mengandung resiko, yakni adanya target-target baru kalangan ilmuwan itu sendiri. ${ }^{17}$ Dengan keinginan untuk mengatasi masalah melalui pengembangan ilmu, semakin dirasakanlah kegagalan teori sosial yang digeluti. ${ }^{18}$ Pengembangan ilmu perlu disertai dengan komitmen untuk mengatasi persoalan bangsanya.

Pada tataran praktis, Indonesia sepertinya belum merumuskan secara jelas dan menerapkan secara konsisten politik keilmuan ini. ${ }^{19}$ Kita juga tidak punya

16 Belakangan ini kita menyaksikan perubahan sosok universitas. Lembaga ini semakin kentara sosoknya pelaku industri pendidikan, dan dalam pergeseran ini tidak pernah ada rumusan tentang politik pengembangan ilmu yang hendak dilakukan selain memastikan menjadi mata rantai industri itu sendiri. Dalam skema industrialisasi pendidikan itulah ilmu sosial netral dikembangkan, dan dalam kekosongan politik keilmuan ini Indonesia menjadi tetap menjadi lokasi. untuk memberlakukan teori-teori universal tersebut. Dalam konteks inj, obsesi universitasnya untuk tampil sebagai $W C R U$ perlu sensitif terhadap persoalan-persoalan di atas. Syukur kalau memang kita memformulasikan politik keilmuan ini dalam skema WCRU itu sendiri.

17 Redefinisi peran intelektual ini salah satunya dipantik oleh tulisan Julien Benda mengeni penghianatan kaum intelektual

18 Lebih lanjut baca misalnya baca, Dick Hartoko. Golongan Cendekiawan, Mereka yang Berwmab di Angin: Sebuah Bunga Rampai, (Jakarta: Gramedia. 1981); Aswab Mahasin, dan Ismet Nashir, (ed). Cendekiawan dan Politik, (Jakarta: LP3ES. 2004); Ignas Kleden. Sikap Imiab dan Kritik Kebudayaan, ( Jakarta: LP3ES. 1987); AE Priyono, (ed). Krisis Ilon-Ilmu Sosial dalam Pembangunan di Dunia Ketiga, (Yogyakarta: PLP2M. 1984); Dawam Rahardjo, Intelektual, Intelogensia, dan Perilaku Politik Bangsa: Risalab Cendekiawan Muskim (Kumpulan Karangan Dawam Rabardjo), (Bandung: Mizan. 1993); Nico G Schulte Nordholt dan Leontine E Visser, (ed). Ilmu Sosial di Aria Tengyara. Dari Partikularisme ke Universatisme, Oakarta: LP3ES. 1997); Daniel Dhakidae, Cendekiawan dan Kekuasaan dalan Negara Onde Bark, Jakarta: Gramedia Pustaka Utama. 2003); Yudi Latif, Inteligensia Muslim dan Kuasa: Genealogi Intelegensia Muslim Indonesia Abad ke-20, (Bandung: Mizan. 2005); serta Hadis dan Daniel Dhakidae, (ed). I bnu Sosial dan Kekuasaan di Indonesia, (Jakarta: Equinox Publishing Indonesia. 2006).

${ }^{19}$ Sebagai contoh, ketika menyekolahkan para pemuda pilihan untuk belajar ke luar negeri, yang kita banyangkan hanyalah peningkatan sumberdaya manusia. Kita tidak punya rencana yang jelas apa yang harus mereka hasilkan setelah pulang dari luar negeri. Karena tidak 
formula yang jelas ke negeri mana para dosen ilmu-ilmu sosial harus belajar karena tidak ada spesifikasi ilmu yang hendak dikembangkan, dan masalah apa yang harus diatasi. Keputusan untuk itu diambil alih oleh mereka yang menawarkan beasiswa belajar di luar negeri, mereka yang ingin mendatangkan kita. Padahal, ada kecenderungan dari universitas-universitas di negara-negara pascakolonial, tidak terkecuali universitas di negeri ini, menjadikan univeritasuniveritas di negara-negara maju rujukan pengembangan. Baik secara alamiah (nature) maupun by design, relasi tersebut dapat menimbulkan efek ketergantungan terhadap perguruan tinggi di negara industri maju. ${ }^{20}$ Tanpa kejelasan arah politik pengembangan ilmu, komunitas yang secara keilmuan

konsistennya pelaksanaan stratcgi pengebangan ilnu dan teknologi di masa Prof. Dr. BJ. Habibie menjadi menteri Riset dan Teknologi, investasi besar-besaran untuk pengembangan surnberdaya manusia yang memberikan harapan besar saai itu, kini justru diperlakukan sebagai beban. Entah apa yang telah terjadi, tidak sedikit dari mereka yang masih berada di luar negeri setelah memperoleh gelar doktornya.

20 Untuk menjelaskan point ini, mari kita cermati Modern Indonesia Project yang dikembangkan Amerika Serikat di Comell University. Sedikit banyak proyek memiliki fungsi menggiring pemikiran politik dan ekonomi di negeri ini. Salah satu karangan penting terkait hal tersebut ditulis oleh David Ransome, The Berkeley Mafia (1970), yang diulas oleh Bruce Glassburner, "Politik Ekonomi dan Pemerintahan Orde Baru", dalam Arndt [ $\Lambda$ rndt, HW (ed), Pembangunan dan Pemerataan: Indonesia di Masa Orde Baru, (Jakarta: LP3ES, 1987). Menurut Ransome dikutip Glassburner, Kepala Perwakilan Ford Foundation di Jakarta tahun 1950-an, Michael Harris, "dituduh" telah berusaha mengarahkan pelajaran ekonomi di universitasuniversitas Indonesia kepada pemikiran Barat ortodoks, sebagai suatu usaha mencegah "kekirikirian", khususnya "Soekarnoisme". Alat yang dipakai berupa bantuan (yrant) Ford Foundation (Rockerfeller Foundation, dan Fulbright) dalam jumlah besar kepada Indonesia, yang diatur universitas-universitas Amerika, untuk studi lanjut di Amerika maupun membiayai tim Amerika yang menjadi penasihat dalam kurikulum dan yang berhubungan dengan itu, atau mengajar di Indonesia. Tujuan utama Ransome dengan karangannya adalah menyalahkan keterlibatan University of California (Berkeley) dan Ford Foundation dalam upaya pembersihan betdarah dan penghapusan Partai Komunis Indonesia (PKI), serta yang terpenting adalah ascsiasi intelektual ini dimaksudkan untuk penerapan ideologi ekonomi komprador (comprador economy ideology) dan kebijakan ekonomi yang sesuai dengan kepentingan Amerika. Di luar Berkeley, catat Simon Philpott, Meruntubkan Indonesia: Politik Postkolonial dan Otoritarianisme, ( Yogyakarta: LKIS, 2002), ada juga keterlibatan kuat dari Massachusetts Institute of Technology (MIT) dan Comell University. Bahkan di Cornell, Ford Foundation, juga mendanai pendirian Modern Indonesia Project, suatu program studi Indonesia yang paling berpengaruh selama empat puluh tahun terakhir. Dalam perjalanannya, jumlah donor semakin besar dan semakin beragam latar geografis, bidang, kepentingan, ideologi, dan karakteristik lainnya (menyebut sejumlah contoh: dari Eropa Barat termasuk Skandinavia, Eropa Timur, Asia Timut, Timur Tengah, dan Australia) 
difasilitasi dengan otonomi mudah digiring oleh agenda-agenda negara-negara maju. ${ }^{21}$

Kalau komitmen kita adalah menjalankan amanat untuk mencerdaskan kehidupan bangsa yang notabene rentan disetir oleh bangsa-bangsa lain, menampilkan universitas sebagai $W C R U$ haruslah didasari oleh kemampuan menjadi sumber pengembangan ilmu di negeri sendiri, bukan hanya membaritu bangsa lain mengambil ilmu dari halaman kita. Hal yang sebaliknya juga penting. Melalui WCRU ini kita harus dapat mengambil kecerdasan mereka untuk mencerdaskan kehidupan bangsa ini. ${ }^{22}$ WCRU harus dipastikan tidak berfungsi

${ }^{21}$ Kita tahu ada cerita banyak paket beasiswa yang diberikan, ada asistensi pendirian dan pengembangan jurusan (termasuk pendampingan penyusunan kurikulum serta sistem perkuliahan), penyediaan bahan-bahan literatur akademik, bantuan research grant, fellowship, student exchange, dan lain sebagainya. Hal ini diperteguh oleh industrialisasi penerbitan setta kemajuan teknologi informasi yang dikembangkan di negata-negata maju, akibatnya arus lalu-lintas pengetahuan bergerak menjadi sangat agresif: cepat, mudah, dan murah, namun tanpa menanggalkan coraknya yang cenderung satu arah (one way distribution) Kondisi demikian menyebabkan posisi awal (hingga kini) pengembangan keilmuan di mayoritas negara pascakolonial bercorak "mencarl ke luar" (outward looking) daripada secara induktif menggali khasanah yang dimilikinya (indigen). Sebagai salah satu indikator, Smith Smith, Linda Tuhiwai, Dekolonisasi Metodologi. Yogyakarta: Insist Press. 2005. hal: xi., berujar, bahasa dan kutipan teks dalam karya-karya ilmiah yang dihasilkan seringkali menjadi tanda-tanda paling jelas dari tradisi teoritik seorang penulis. Seperti juga ditegaskan Kleden, hal.17, yang menulis secara nyinyir: "Para ilmuan sosial di negara-negara Dunia Ketiga mulai sadar dan kemudian merasa malu bahwa sesungguhnya mereka terlalu lama hidup sebagai sarjana imitasi. Ketika mereka ingin mengatakan sesuatu, maka jang mereka lakukan adalah hanya sekadar mengulang atau engutip kata-kata gurunya dari Barat, dan ketika mereka ingin menentang gurunya, mereka praktis tidak berbuat lain daripada mencari guru-guru lain yang juga dari Barat. Dengan demikian, mereka mempelajari Dahrendorf agar mampu mengkritik Parsons; mereka mendengar Popper jika mereka harus mengatakan sesuatu menentang Marx, mereka menolak Max Weber atas Habermas, dan mereka menonjok Levi Strauss dengan tinju Paul Ricoeur." Tesis/asumsi tersebut pun diuji dalam kajian ini.

${ }^{22}$ Point ini saya kedepankan lagi karena ada kesan bahwa realisasi gagasan tentang WCRU lebih kental dengan nuansa manajerial dari pada pengembangan ilmu. Simpul dinamikanya ada pada pengelola atau pengurus, bukan pada ilmuwannya. Kata-kata kunci yang dipakai adalah tipikal dalam pengembangan manajemen, yakni standarisasi; pengendalian mutu dan sebagainya, bukan teori ini dan teori itu. Sepertinya pengembangan sisi keilmuan dianggap sudah tidak perlu diapa-apakan lagi (given), cukup dilekatkan pada rutinitas manajemen universitas betikut unitunit kerjanya. Secara politik, menjadi WCRU tidak berarti apa-apa bila ilmu, yang pertaruhan utama universitas bukan menjadi inti persoalannya. Profesionalitas pengelolaan dan kemapanan lembaga memang menjadi pra-syarat, namun muaranya tentulah pengembangan ilmu dan pengembangan diri kita sebagai bangsa. 
sebagai instrumen konglomerasi pengetahuan yang secara keilmuan justru memposisikan Indonesia semakin ketagihan dan tergantung.

Citra universitas kita di arena internasional memang harus semakin menonjol, namun perannya sebagai produsen ilmu dan bukan sebagai penyebar atau penyalur ilmu yang dikembangkan oleh lembaga-lembaga di luar negeri. Jangan sampai bangsa ini akan semakin kecanduan dengan resep-resep yang diturunkan dari teori-teori sosial di negara lain. Jangan sampai kita yang dituntut menyesuaikan diri terhadap standar yang berlaku di negara lain, karena kita tidak sanggup memperjuangkan standar alternatifnya.

Antisipasi kritis tentang WCRU tersebut di atas tidak dimaksudkan untuk mempersalahkan siapa-siapa, melainkan sekedar mengingatkan diri sendiri dan para ilmuwan yang menekuni ilmu sosial di negeri ini. Jangan sampai kita terbuai oleh sistem peringkat yang diberlakukan dalam $W C R U .{ }^{23}$ Yang jelas, universitas-universitas di negara maju lebih memiliki kontrol terhadap ilmu yang mereka kembangkan. Untuk itu, ilmuwan sosial perlu menentukan alat ukur sendiri untuk menunjukkan kemajuan kita dalam menggarap persoalan yang kita lebih tahu, kita lebih mampu. Ukuran itu harusnya bersifat substantif, misalnya keberhasilan mengembangkan mazhab baru dalam bidang kajiannya. Paling tidak, ukurannya adalah tidak kecolongan. ${ }^{24}$

${ }^{23}$ Ada kebanggaan tersendiri ketika universitas kita masuk dalam peringkat 100 besar dunia. Yang menarik, ada era dimana disiplin ilmu sosial di UGM ini masuk dalam peringkat yang sangat membanggakan. Sungguhpun demikian perlu diingat bahwa yang menjadikan ilmu sosial di UGM masuk dalam peringkat tersebut bukanlah kontribusi keilmuan dalam pengembangan ilmu. Salah satu penjelasnya adalah banyaknya mahasiswa asing yang belajar bahasa dan bud2ya Indonesia. Sehubungan dengan hal itu penting bagi kita untuk tidak terbuai dengan peringkat, dan lupa dengan tantangan yang sesungguhnya, yakni mengembangkan ilmu itu sendiri.

24 Ijinkan saya menggunakan contoh dalam pengembangan teori politik, khususnya teori demokrasi. Kita belum lupa bahwa konsep musyawarah begitu gencar di ditonjolkan pemerintah, dan para ilmuwan politik begitu genjar juga mencercanya. Musyawarah telah dipolitisir oleh para pemimpin kita waktu itu untuk menyembunyikan berbagai kepentingannya, dan sejalan dengan hal itu, ilmuwan justru tidak mengembangkan teori tentang musyawarah ini. Setelah Orde Baru betlalu, kita dikejutkan oleh demokrasi permusyawaratan (deliberative democracy) yang dikembangkan oleh ilmuwan manca negara. Ironis bukan ? Kita harus belajar sesuatu kepada orang lain tentang hal yang pernah dan mungkin masih menjadi watak budaya kita. Imuwan politik harus menanggung malu karena tidak punya kejelasan arah pengembangan 


\section{E. Belajar dari Negara Lain}

Usulan untuk merumuskan politik keilmuan dalam rangka go international tidaklah mengada-ada. Hal itu juga dilakukan oleh negara lain. Teori ketergantungan yang dikembangkan oleh para ilmuwan di negara-negara Amerika Latin, misalnya, menyediakan pijakan bagi perpolitikan di negeri itu untuk memutus ketergantungan politik-ekonomi mereka dari negara-negara industri maju. ${ }^{25}$ Sebab model pembelajaran yang dikembangkan adalah model yang transformatif. Semua itu bisa dilakukan ketika metode pembelajaran kritis direproduksi dan diterapkan.

Hal yang setara dilakukan oleh para ilmuwan di Asia Timur. Di negeranegera di kawasan ini, para ilmuwan sosial mendapat kepercayaan besar untuk menjadi arsitek kebijakan pembangunan dan industrialisasi. Formula kebijakan yang diterapkan kemudian dilabeli sebagai teori developmental state. Berkat upaya merekalah kawasan Asia Timur mengemuka sebagai pusat kekuatan baru perkembangan ekonomi dunia.

Belajar dari negera-negara tersebut di atas, komunitas ilmu sosial mengagendakan proses kolektif untuk merumuskan politik pengetahuan untuk negeri mereka. Baik penerapan teori ketergantungan tersebut di atas, maupun praktek industrialisasi yang kemudian diperlakukan sebagai penerapan teori developmental state ini, tetap menyimpan semangat nasionalistik di balik pengembangan dan penerapan ilmu pengetahuan. ${ }^{26}$

teoti politik dalam komunitasnya. Semoga hal semacam ini tidak terjadi dalam ilmu sosial yang lain.

${ }^{25}$ David Lehmann, Dependencia: An Ideological History, Institute of Development Studies at the University of Sussex, 1986.

${ }^{26}$ Nasionalionalisme dalam pengembangan ilmu, dengan mudah dimentahkan sebagai ketidakmatangan dalam berilmu atau pengembangan ilmu. Menjadi ilmuwan haruslah netral, menghasilkan teori yang universal. Itulah ajaran yang selama ini kita pegang dan kita ajarkan kepada para mahasiswa. Ajaran ini menutup-nutupi kenyataan bahwa pengembangan ilmu itu berlangsung bersamaan dengan pengembangan relasi intemasional yang, diam-diam member keuntungan lebih kepada yang tahu. Kalau dibaca secara skeptis: relasi intemasional ini 
Para ilmuwan di masa Orde Baru pun telah mencoba untuk bekerja dalam bingkai developmental state tersebut. Nasionalisme keilmuan ini tidak tereproduksi secara seksama. Lebih lagi, prestasi Indonesia tidak segemilang prestasi rekanrekannya di negara Asia Timur yang lain. Mimpi mewujudkan Indonesia sebagai suatu developmental state pada masa Orde Baru terpeleset menjadi predatory state. Sambil mempidatokan pembangun, agen-agen yang mengemban tugas negara diam-diam mengembangkan peran tambahan: menjadi pemangsa kesejahteraan rakyat. Namun diagnosis adanya watak predatorik ini hanya dikomunikasikan dan dipahami bersama di antara para ilmuwan, karena ilmuwan memilih untuk menjaga jarak dan tampil sebagai pengamat.

Dalam kebingungan menanggulangi watak pemangsa ini, para ilmuwan berhasil menggiring proses roerientasi kebijakan secara besar-besaran. Semangatnya jelas, melucuti atau meminggirkan kekuasaan negara. Reorientasi inị juga dikenal dengan sebutan liberalisasi. Kalau di negeri ini terjadi liberalisasi secara besar-besaran, medium utamanya adalah universitas beserta para ilmuwannya. Liberalisasi didahului dengan popularisasi teori-teori yang dibangun di atas paham liberal. Liberalisme ini merasuk dalam perwacanaan para ilmuwan sosial. Apa yang terjadi selanjutnya? Kebijakan-kebijakan yang mereka sarankan atau mereka advokasikan secara diam-diam memfasilitasi negara-negara industri maju memperkokoh cengkeramannya terhadap negaranegara berkembang.

\section{F. Ilmu Sosial Transformatif}

Ilmu sosial yang dimaksudkan dalam tulisan ini mencakup berbagai disiplin, termasuk di antaranya sosiologi, ilmu politik, ilmu ekonomi, antropologi, sejarah, ilmu hukum dan sebagainya. Istilah transformatif di sini dipakai dalam pengertian yang longgar, sekedar untuk menandai cara kerja ilmuwannya yang tidak hanya berjuang untuk menjawab pertanyaan-pertanyaannya sendiri, namun hirau dan pada gilirannya mencurahkan dedikasinya untuk menjawab pertanyaan-pertanyaan masyarakatnya. Muara dari kegiatan pengembangan ilmu

membiarkan yang kurang pintar tetap tidak sadar kalau, dari waktu ke waktu dan dari berbagai sisi, tetap dibodohi. 
yang ditekuni bukan hanya stok pengetahuan yang lebih banyak dan lebih baik, melainkan juga kapasitas mengatasi masalah-masalah sosial. Sungguhpun demikian, ilmu sosial transformatif bukanlah ilmu tentang ketrampilan (vokasi). Watak transformatif ilmu sosial bukan ditentukan oleh ketrampilan teknis, melainkan ditentukan oleh komitmennya untuk mewujudkan realitas baru sesuai dengan yang diteorisasikannya. Ketika membahas good governance misalnya, kehirauannya bukan hanya pada ukuran dan ciri-ciri good governance, melainkan menghasilkan perilaku bersama yang memenuhi ukuran dan ciri-ciri yang dimaksudkan. Realita baru ini merupakan ekspresi dari komitmen etik yang di reproduksi melalui proses pendidikan yang dikelola oleh universitas.

Pengembangan ilmu sosial transformatif mensyaratkan kepiawaian dalam tiga dimensi filsafat ilmu: yakni ontologi, epistemologi dan aksiologi. Pencanggihan di tiga dimensi ini perlu dilakukan dalam kebulatan. Hanya saja, yang selama ini bermasalah adalah sisi epistemologis dan sisi aksiologis. Jelasnya, watak transformatif perlu didasari kejelasan pilihan epistemologisnya: menolak asumsi bahwa kegiatan pengembangan ilmu netral dari praktek adu kuasa. Kalaulah penelitian dan kegiatan-kegiatan keilmuan dilakukan secara obyektif sebagaimana dituntut kaum posisitivis, akumulasi pengetahuan yang berlangsung tidak mungkin mengelak dari kenyataan bahwa pihak yang lebih tahu dapat dan biasa menyiasati pihak lain karena pengetahuannya. Oleh karena itu, dalam pengembangan ilmu sosial transformatif keberadaan metode keilmuan mengedepankan obyektivitas tidak harus ditolak, namun harus disadari kenaifannya, dan dicarikan cara untuk mengkompensasi keperluannya untuk transformatif. ${ }^{27}$ Watak transformatif juga ditentukan oleh pilihan aksiologisnya. Ilmu sosial dikembangkan bukan sekedar untuk pengembangan ataupun akumulasi teori melainkan juga untuk memperbaiki relasi sosial yang terjalin, untuk menghasilkan realitas sosial yang dinilai lebih baik.

Studi dalam skala terbatas yang telah dilakukan selama ini menunjukkan bahwa kemandegan pengembangan ilmu dari sisi ontologis tidak diimbangi

27 Kaidah netralitas ilmu, mungkin tidak problematik untuk ilmu eksakta ataupun ilmu alam. Pengembangan ilmu sosial transformatif, juga tidak harus melarang diberlakukannya kaidah kenetralan ini. Hanya saja, hal itu harus dikawal dengan rumusan politik keilmuan yang jelas, sebagaimana dijelaskan di depan. 
dengan kepiawaian epistemologis. Di samping itu, ilmu tidak berkembang karena, secara aksiologis ilmu dipelajari sekedar untuk tahu atau tahu lebih banyak. ${ }^{28}$ Sangat sedikit semangat advokasi yang direproduksi dari kegiatan keilmuan yang dipelajari.

Kepincangan dalam penguasaan dan penerapan tiga dimensi filsafat ilmu ini ternyata sejalan dengan tiga tipe pembelajaran kolektif yang telah dirumuskan oleh Carlile sebelumnya. Matrik 1 memperlihatkan hal ini. Kebuntuan pengembangan ilmu ketika obsesi ontologis dikejar tanpa penguasaan epistimologis yang disertai dengan kelatahan aksiologis. Ilmu dikembangkan sekedar karena mau tahu apa yang diketahui orang lain. Model pembelajaran komunitas ini berwatak sintaktis karena ilmuwan yang bersangkutan tidak sempat memahami duduk persoalan yang dipelajari. Ketika menengok kembali model pembelajaran yang berlangsung di masa lalu; kita menemukan gejala semacam ini. Sebagai contoh, ketika mengajarkan mata kuliah tentang sistem, kami tidak sempat mempersoalkan mengapa konsep sistem ditawarkan, dan pengajarannya lebih pada pertanyaan: "apakah sistem itu?". Reproduksi kemampuan menghasilkan pengetahuan akan lebih terlihat sekiranya yang dilakukan adalah mengajari berpikir sistem dan memperjuangkan sistem. Pembelajaran akan lebih hebat lagi sekiranya keberhasilan pembelajaran diukur dari kemampuan menerapkan sistem dalam praktek kehidupan seharihari.

Matrix. 1.

Peta Kecanggihan Filosofis untuk Mengembangkan Kapasitas Keilmuan

\begin{tabular}{|l|c|c|c|}
\hline \multirow{2}{*}{ Model Pengembangan } & \multicolumn{3}{|c|}{ Sisi Kecanggihan Filosofis } \\
\cline { 2 - 3 } & Ontologis & Epistemologis & Aksiologis \\
\hline Sintaktik & $\sqrt{|c|}$ & \\
\hline Semantik & \multicolumn{3}{|c|}{} \\
\hline
\end{tabular}

${ }^{28}$ Purwo Santoso, Nur Azizah, Nanang Indra K, Joash Tapiheru. E.S., Zarah Ika, "Sinergi Pengembangan Ilmu Pemerintahan Dengan Pembaharuan Tata Pemerintahan Lokal", Monograph on Politics and Government, Vo. 4 No. 1 Tahun 2010. 
Transformatif

Penguasaan epistemologis memungkinkan ilmuwan memahami berbagai pemahaman tentang suatu hal, dan adanya hal itu memungkinkan dirinya menarik makna. Perluasan kompetensi dari melulu memburu pemahaman ontologis dengan memperkuat basis epistemologi memungkinkan ilmuwan mengembangkan pembelajaran yang tarafnya semantik. Kembali pada contoh sebelumnya: pembelajaran tentang sistem. Targetnya bukan hanya bagaimana mereproduksi cara berpikir sistemik. Pengembangan ilmu transformatif berlangsung manakala pertanyaan ontologi diajukan karena pertanyaanpertanyaan aksiologis. Kalaulah belajar sistem dan caca berpikir sistemik, pembelajaran itu didorong oleh keinginan untuk membentuk sistem untuk situasi tertentu. Kuatnya dorongan untuk menjawab pemasalahan yang menggejala membutuhkan kerangka epistemologis untuk menjelaskanya.

Politik pengembangan ilmu yang kita dambakan, sebetulnya justru tersirat dari keharusan untuk mengkaitkan Tri Dharma Perguruan Tinggi sebagai suatu kebulatan. Spirit untuk mengamalkan Tri Dharma Perguruan Tinggi sebagai suatu kebulatan, perlu ada pada setiap ilmuwan. Pengelolaan universitas, sebagaimana semakin terlihat belakangan ini, semakin didasari oleh keperluan untuk memastikan masing-masing dharma perguruan tinggi tersebut bersifat saling menunjang. ${ }^{29}$ Istilah transformatif, yang dikemukakan dalam tulisan ini sebetulnya hanyalah suatu penegasan bahwa muara dari aktualisasi kegiatan keilmuan, dalam hal ini pendidikan dan penelitian, adalah pengabdian pada masyarakat Politik pengetahuan yang kita perlukan mengharuskan pembalikan logika konvensional. Pengabdian pada masyarakat, bukanlah beban tambahan yang harus dipilih, melainkan justru basis pijakannya.

Dalam interaksi dengan mitra-mitra kerja dari luar negeri, tidaklah mudah kita menuntut atau mengajak mereka ambil bagian dalam menunaikan misi pengabdian pada masyarakat. Sebagai contoh, kerja sama intemasional dengan

29 Purwo Santoso dan Kacung Marijan, "Demokratisasi Indonesia Secara Kontektual, Makalah Kelompok Kerja Demokratisasi”, Disampaikan dalam Konvensi Kampus VII dan Temu Tahunan XIII Forum Rektor Indonesia di Universitas Sriwijaya, Palembang pada tanggal 13-15 Januari 2011. 
sejumlah Indonesianis untuk meneliti proses demokratisasi. Karena mereka bukan orang Indonesia, mereka tidak punya komitmen untuk mendorong proses demokratisasi melalui riset tersebut. Mereka sangat antusias untuk menghasilkan laporan yang baik dan menerbitkannya, namun tidak merasa perlu untuk memfasilitasi penggalangan jejaring aktivis pro-demokrasi.

\section{G. Menggalang Transformasi}

Apa yang bisa dan perlu dilakukan agar WCRU ditopang oleh politik keilmuan yang kokoh? Bagaimana memastikan ilmuwannya sanggup keluar dari krisis keilmuan yang melilinya dan memiliki kontribusi bagi penanganan masalah-masalah sosial di negeri ini? Serangkaian proses reorientasi sangat perlu dilakukan, baik pada tataran konsep maupun praktek.

1. Berangkat dari evaluasi kinerja ilmuwan.

Prasyarat untuk bisa berkembang adalah memiliki keberanian untuk mengevaluasi diri sendiri dan mengambil langkah yang tepat berdasar evaluasi itu sendiri. Pertanyaannya, pada level mana evaluasi itu harus dilakukan. Seberapa jauh unit-unit ini menata diri mengembangkan ilmu yang digelutinya?

Materi evaluasinya bukan hanya seberapa bagus mereka mengelola proses pembelajaran, melainkan juga memerankan diri sebagai unit pengembangan ilmu. Kalau perlu, universitas mentargetkan lahir dan berkembangnya mahzab keilmuan tersendiri sehingga komunitasnya dikenal dari kekhasan gaya pemikirannya, bukan karena gelar dan jabatannya. Jika usulan ini disetujui maka, ilmuwan sosial perlu memiliki ketegasan aksiologis, sebab ilmu sosial dikembangkan bukan untuk ditimbun melainkan untuk mengatasi masalahmasalah sosial.

Sebagai contoh, di Universitas Gadjah Mada disepakati formula pembagian peran. Formula ini dikenal dengan istilah SADA, singkatan dari Sentralisasi Administrasi dan Desentralisasi Akademik. Dengan adanya desentralisasi akademik ini maka pelaku dan tanggung jawab pengembangan ilmu ada pada unit-unit kecil, setidaknya Jurusan dengan Program-program Studinya dan pusat-pusat penelitian. Sehubungan dengan agenda pengembangan WCRU ini sungguh sangat disayangkan kalau desentralisasi akademik yang telah 
diberlakukan tidak bermuara pada aktualisasi diri para ilmuwan dalam pengembangan ilmu di bidangnya masing-masing. Skema desentralisasi akademik akan menjadi hal yang sia-sia bilamana tidak bermuara pada kebangkitan ilmuwan dan ilmu sosial Indonesia. Tidak optimalnya aktualisasi otoritas akademik yang telah didesentralisasikan, dapat menjadikan penampilan WCRU pincang. ${ }^{30}$ Dari segi peringkat hagus, namun memprihatinkan dari segi kontribusinya. Oleh karena itu, para ilmuwan sosial dituntut untuk mengevaluasi dirinya sendiri dan mengusulkan serta mewujudkan langkahlangkah yang diperlukan.

Sebetulnya skema evaluasi sudah ada dan sudah dijalankan. Pengukuran terhadap kinerja unit-unit akademik ini memang telah dilakukan oleh Direktoral Jendral Pendidikan tinggi dengan skema EPSBED (Evaluasi Program Studi Berbasis Evauasi Diri). Di samping juga skema akreditasi yang dilakukan oleh Badan Akreditasi Nasional (BAN). Hanya saja, yang diungkap dalam skema ini bukanlah kinerja dalam pengembangan ilmu melainkan kinerja dalam menyelenggarakan proses pembelajaran. Kalaulah kinerjanya suatu program studi diberi nilai ' $A$ ' sama sekali tidak ada jaminan bahwa program studi ini memiliki kaliber ' $A$ ' dalam pengembangan ilmu. Untuk itu perlu perbincangan serius dalam komunitas ilmuwan sosial sendiri untuk merumuskan tolak ukur dan mekanisme pengukuran kinerjanya dalam pengembangan ilmu dan penanganan masalah-masalah sosial yang berlangsung di negeri ini.

2. Transformasi dari kosumen ke produsen.

Ketika go international, ada prasyarat yang kita berlakukan pada diri sendiri: sanggup berperan sebagai produsen ilmu. Dengan demikian keterlibatan kita di

30 Praktek desentralisasi pemerintahan, yang semenjak berakhimya era Orde Baru hendak dilakukan secara besar-besaran di negeri ini, menyajikan pengalaman menarik. Ada pemerintah daerah yang berkembang dan inovatif karena diberi otonomi. Namun, ada juga pemerintah daerah yang justru tidak jelas kinerjanya ketika diberi kesempatan berotonomi. Mekanisme dan prosedur pemerintahan di sejumlah daerah justru ada yang semakin kacau balau ketika daerah tersebut mendapatkan luapan daya yang melampaui daya serapnya. Apa yang membedakan kinerja satu daerah dibandingkan dengan daerah lain dalam menggunakan otonominya? Yang membedakan adalah kemampuan menggunakan otonomi secara bertanggung jawab, menggunakan sesuai dengan misi pemberian otonomi itu sendiri. 
kancah internasional tidak hanya "mengimpor" namun juga "mengekspor" pengetahuan. Sehubungan dengan hal itu, kita perlu mewaspadai godaan untuk mudah puas, atau tanpa sadar hanya menjadi pengimpor pasif. Mengapa? Selama ini terjadi hubungan yang tidak sama dan tidak seimbang antara negaranegara industri maju dengan negara-negara berkembang seperti negeri kita ini. Tersedianya teknologi informasi dan berbagai fasilitas lain telah memudahkan ilmuwan sosial mengakses berbagai kajian yang ada di muka bumi ini. Tapi, jangan-jangan hal ini hanya memastikan bahwa ilmuwan sosial di negeri ini hanyalah konsumen bertaraf global, bukan produsen yang sanggup memasarkan produk-produknya di arena internasional. Pertanyaannya kemudian adalah bagaimana keluar dari zona kenyamanan sebagai konsumen dan secara lambat tapi pasti hadir sebagai produsen dan "eksportir" ilmu atau teori-teori sosial?

Selama ini ilmuwan sosial memelihara salah kaprah dan pada saat yang sama memilih tinggal di zona nyaman sebagai konsumen. Dalam kultur akademik yang berlaku, ilmuwan memang perlu merujuk dan menyebut sumber pengetahuan dengan jelas dan jujur. Hanya saja, kaidah ini-tergelincir menjadi ketidakberanian berargumentasi. Hal yang paling sulit yang pernah penulis alami dalam pembimbingan skripsi, thesis dan desertasi, yaitu membangun proposisi argumentatif dalam tugas akhir mandiri yang mereka kerjakan. Nada-nadanya, hal ini terkait kultur pembelajaran ilmu sosial yang dalam banyak kasus, didasari semangat mentransfer bukan mentransformasikan pengetahuan.

Kesulitan, tepatnya ketidakberanian membangun argumentasi, sepanjang yang penulis deteksi selama membimbing para calon sarjana, calon master dan bahkan calon doktor, bersumber dari ketidakpiawaian metodologis. Oleh karena itu, program-program studi yang mengampu ilmu sosial perlu menjamin dapat diterapkannya berbagai pilihan mazhab keilmuan. Dengan ditawarkannya berbagai pilihan mazhab dan pendisiplinan para ilmuwan dalam menggunakan mazhab pilihannya, maka muncullah permasalahan-permasalah baru yang mengundang perdebatan, dan adu piawai menggunakan metodologi keilmuan masing-masing. Dengan cara itu pula muncul berbagai tawaran teori yang pada gilirannya mengundang perdebatan dan pemahaman serta solusi baru. 
Untuk mencapai situasi dimana kontroversi ilmiah justru menghasilkan temuan-temuan baru, para ilmuwan yang bersangkutan dituntut untuk memiliki kematangan metodologis. Untuk itu, perlu dipertimbangkan pentingnya mengembangkan support system untuk pengembangan kapasitas metodologis. Kita bisa belajar dari London Scbool of Economics and Political Science yang mendirikan Methogology Institute. Lembaga ini bertanggung jawab untuk mengawal kompetensi metodologi keilmuan dan metode penelitian civitas akademikanya. Setidaknya semua kandidat doktor harus belajar di lembaga ini, meskipun tidak harus mengumpulkan SKS (satuan kredit semester).

3. Imuwan sosial bersedia untuk melakukan social crafting.

Tanggung jawab utama bagi pengembangan ilmu melekat dalam diri para ilmuwan yang bersangkutan, bukan pada pimpinan universitas ataupun pimpinan fakultas. Ilmu dapat berkembang manakala ada kegelisahan di kalangan ilmuwan itu sendiri, dan kegelisahan tersebut dijabarkan dalam langkah-langkah konkrit yang pada gilirannya terakumulasi menjadi agenda kolektif. Upaya untuk mengungkit kegelisahan ini sudah berlangsung, hanya saja belum terlihat sebagai geliat kolektif yang mengobsesi komunitas keilmuan di dalamnya. Untuk itu diperlukan setidaknya: (1) pengrajin jejaring ilmuwan, (3) mobilisasi kegelisahan, (3) konversi kegelisahan menjadi karya-karya dan amalan ilmiah, (4) reproduksi tapak akademiknya menjadi kultur akademik.

Penggalangan jejaring komunitas keilmuan jelas berlangsung, hanya kalaulah tidak sporadis belum cukup menyelurub. Pengembangan jejaring ini akan memiliki efek dahsyat ketika dikemas dalam agenda-agenda yang menggairahkan obsesi akademik yang ada. Untuk itu, yang dipertanyakan bukan hanya agenda-agenda riset unggulan universitas ini, melainkan juga seperti apakah corak agenda tersebut? Jawaban atas pertanyaan ini tentu saja terkait dengan identitas diri dan jati diri tentang universitas ini.

Sekali lagi, ketrampilan social crafting sangat diperlukan untuk menggalang agenda berbasis kegelisahan kolektif dalam komunitas keilmuan yang ada. Agar kegelisahan ini terlampiaskan, tokoh-tokoh kunci dalam komunitas yang ada dituntut untuk mengoptimalkan kepemimpinannya demi menghasilkan karyakarya yang menjawab tantangan yang telah dirumuskan. Perlu sejumlah inovasi 
agar hal semacam ini terus-menerus berlangsung. Lebih dari itu, perlu inovasi untuk memungkinkan produk-produk keilmuannya terpapar kepada publik yang pada gilirannya merangsang permintaan lebih lanjut dari universitas.

Salah satu contoh yang dapat diambil, yakni inisiatif komunitas Jurusan Politik dan Pemerintahan Fakultas Ilmu Sosial dan Ilmu Politik di Universitas Gadjah Mada. Menyadari bahwa wadah kelembagaan yang sudah ada tidak mewadahi aktivitas-aktivitas yang dikembangkan, maka Jurusan ini mengembangkan unit baru di luar standar kelembagaan universitas. Unit baru ini mulai memperkenalkan diri dengan nama PolGov (Research Centre on Politics and Govermment). Jurusan ini bermaksud untuk mengaktualisasikan tri dharma pendidikan tinggi dalam komunitasnya. Idenya bukan untuk menjadikan komunitas ini eksklusif, melainkan untuk menjaga agar tri dharma perguruan tinggi bisa dikelola secara terpadu. Dengan inovasinya, komunitas ini mencoba untuk mencerdaskan dirinya.

Dengan inovasi tersebut di atas, komunitas keilmuan di dalamnya bermaksud mengembangkan pembelajaran berbasis riset, dan riset yang hasilnya memperkuat pembelajaran. Untuk memudahkan komunitas ini melepas karyakaryanya ke publik, kegiatan riset dan advokasi ditambah lagi dengan adanya unit yang menjalankan aktivitas publikasi. Dalam konteks ini, social crafting yang berlangsung bermuara pada pengembangan kapasitas kelembagaan, yang pada gilirannya memfasilitasi pengembangan ilmu melalui karya-karyanya. Dengan karya-karya yang ada, komunitas ini mencoba untuk go intermational. Salah satu agenda yang diusung oleh komunitas ini adalah merumuskan demokrasi dan desentralisasi yang mensejahterakan. Dengan bingkai agenda ini, komunitas ikut berkontribusi dalam mewamai perdebatan tentang hal itu baik di forum nasional maupun internasional.

\section{H. Penutup}

Sebagai penutup dari keseluruhan tulisan ini perlu dikemukakan. Pertama, adanya asimetrisme atau perbedaan cara pandang yang tidak sama dalam pengembangan ilmu, khususnya ilmu sosial. Kealphaan dalam menghayati asimetrisme ketika hendak go intemational bisa berakibat fatal bagi Indonesia 
pada umumnya, dan bagi ilmuwan sosial pada khususnya. Sebelum terlambat, komunitas ilmuwan sosial perlu melakukan serangkaian reorientasi dan pembudayaan hal-hal yang secara filosofis telah digariskan. Lebih dari itu, komunitas keilmuan perlu merumuskan dan menyepakati suatu garis politik yang jelas, garis politik keilmuan untuk Indonesia. Kesepakatan pada tataran operasional tentang hal itu kiranya tidak terlalu sulit untuk di raih mengingat acuan-acuan normatif yang kita miliki, seperti tri dharma perguruan tinggi, sudah cukup jelas memberi acuan. Yang diperlukan adalah imajinasi kreatif dalam menafsitkannya.

Kedua, untuk go intemasional, mau tidak mau, kita harus berangkat dari kondisi dan kepentingan nasional. Belajar dari pengalaman negara-negara Asia Timur, kiprah yang membuat mereka mampu berjaya bukanlah dengan meningggalkan, melainkan justru mempertebal nasionalismenya. Nasionalisme dalam politik keilmuan universitas adalah pengabdian pada masyarakat. Artinya, IVCRU yang nasionalistik adalah yang justru membalik pengabdian pada masyarakat; bukan sebagai beban melainkan pijakan untuk go international. Sejalan dengan hal itu, go international tidak harus meninggalkan "rumah" Indonesia.

Ketiga, ilmu sosial transformatif menuntut kerja keras ilmuwan sosial di dua titik ekstrim: Di satu sisi mereka dituntut untuk mempertebal penghayatan tentang kaidah fisolofi keilmuan, tepatnya memperkokoh penghayatan ontologis berbasis epistemologis yang jelas karena alasan aksiologis tertentu. Namun di sisi lain, mereka dituntut untuk ambil bagian dalam mewujudkan secara konkrit penghayatan filosofis tersebut ke dalam praktek keilmuan seharihari, dalam proses social crafting.

Keempat, meskipun tanggung jawab bagi pengembangan ilmu sosial transformatif pada domain komunitas keilmuan, namun bukan berarti jajaran pengelola universitas boleh lepas tangan. Dalam belitan krisis ilmu sosial yang masih berlangsung, pengkondisian dari sisi manajemen sangat diperlukañ. Sayap keilmuan dan sayap pengelolaan haruslah mengepak bersama agar kita bisa berjaya sebagai IWorld Class Researcb University. Dengan demikian ilmu yang 
dikembangkan ilmuwan sosial bukan hanya menghasilkan kemaslahatan umat manusia, namun juga merupakan ikhtiar untuk mewujudkannya dari Indonesia. DAFTAR PUSTAKA

Abdullah, M Amin. 2006. Islamic Studies di Perguruan Tinggi: Pendekatan IntegratifInterkonektif. Yogyakarta: Pustaka Pelajar.

Amdt, HW (ed), 1987. Pembangunan dan Pemerataan: Indonesia di Masa Orde Baru. Jakarta: LP3ES.

Box-Steffensmeier, Janet M., Henry E. Brady, David Collier.2008. The Oxford Handbook of Political Metbodology. Oxford University Press.

Carlile, Paul R,2004.“Transferring, Translating, and Transforming: An Integrative Framework for Managing Knowledge Across Boundaries". Organization Science, Vol. 15, No. 5 (Sep. - Oct., 2004), hal. 555-568.

Comfort, Louise K..1985.“Action Research: A Model for Organizational Learning". Joumal of Policy Analysis and Management, Vol. 5, No. 1, (Autumn,).

Crossan, Mary M., Henry W. Lane, Roderick E. White.1999.“An Organizational Learning Framework: From Intuition to Institution". Academy of Management Review, Vol. 24, No. 3,

Darity, Willian A Jr (editor in chief), Intermational Encyclopedia of Social Science. 2nd Edition. Volume 8. Macmillan Reference USA.

Dhakidae, Daniel, 2003. Cendekiawan dan Kekuasaan dalam Negara Orde Baru. Jakarta: Gramedia Pustaka Utama.

Dick, Bob, Emie Stringer, Chris Huxham.2009."Theory in Action Research", Action Research, Volume 7(1): 5-12, SAGE Publications.

Dods, Roberta Robin.2004."Knowing Ways/Ways of Knowing: Reconciling Science and Tradition", World Archaeology, Vol. 36(4): 547-557, Debates in World Archaeology, Taylor \& Francis.

Easton, David. 1965 A Systems Analysis of Political Life, Wiley.

Easton, David. 1971.The Political System: An Inquiry Into The State Of Political Science, Knopf. 
Fiol, C. Marlene.1994. "Consensus, diversity and learning in Organizations", Organization Science, Vol. 5, No. 3 (Aug.), hal. 403-420.

Hadis dan Daniel Dhakidae, (ed).2006. Ilmu Sosial dan Kekuasaan di Indonesia. Jakarta: Equinox Publishing Indonesia.

Hartoko, Dick. 1981.Golongan cendekiawan, Mereka yang Berumab di Angin: Sebuab Bunga Rampai. Jakarta: Gramedia.

Huber, George P..1991.“Organizational Learning: The Contributing Process and the Literature". Orgnization Science, Vol. 2, No. 1 February.

Kleden, Ignas.1987. Sikap Ilmiah dan Kritik Kebudayaan. Jakarta: LP3ES.

Latif, Yudi.2005. Inteligensia Muslim dan Kuasa: Genealogi Intelegensia Muslim Indonesia Abad ke-20. Bandung: Mizan.

Kuntowijoyo. 1991.Paradigma Islam: Interpretasi untuk Aksi. Bandung: Mizan. Kuntowijoyo. 2004.Islam sebagai Ilmu: Epistemologi, Metodologi, dan Etika. Yogyakarta: Tiara Wacana.

Mahasin, Aswab dan Ismet Nashir, (ed). 2004.Cendekiawan dan Politik Jakarta: LP3ES.

Mandell, Alan and Lee Herman, 2007. "The Study and Transformation of Experience". Journal of Transformative Education, Vol. 5 No. 4, October, 339-353.

MD, Mahfud, dkk (eds).1999. Kritik Sosial dalam Wacana Pembangunan. Yogyakarta: UII Press.

McKinley, Bryan, Jones Brayboy, Angelina E. Castagno.2008."How might Native science inform 'informal science learning?". Cultural Study of Science Education, (2008) 3:731-750.

Noll, Roget G.1998. Challenges to Researcb Universities. Brookings Institution Press.

Nordholt, Nico G Schulte dan Visser, Leontine E (ed).1997. Ilmu Sosial di Asia Tenggara: Dari Partikularisme ke Universalisme. Jakarta: LP3ES.

Priyono, AE (ed).1984.Krisis Ilmu-Imu Sosial dalam Pembangunan di Dunia Ketiga. Yogyakarta: PLP2M.

Purwanto, Bambang dan Adam, Asvi Warman.2005.Menggugat Historiografi Indonesia. Yogyakarta: Ombak. 
Rahardjo, Dawam. 1993.Intelektual, Intelegensia, dan Perilaku Politik Bangsa: Risalab Cendekiawan Muslim (Kumpulan Karangan Dawam Rabardjo). Bandung: Mizan.

Rosenzweig, Robert M., Barbara Turlington. 1982.The Research Universities and Their Patrons. University of California Press.

Samples, Bob,1999.'Leaming as Transformation", Joumal of Science Education and Technology, Vol. 8, No. 2,

Santoso, Purwo, 2006. "Managing Transformation Toward an International Research University: Lesson-learned From Gadjah Mada University”. Paper presented at UNESCO Forum on Higher Education: Research and Knowledge Colloquium on Research and Higher Education Policy, 29 November - 1 December, UNESCO, Fontenoy, Paris.

Santoso, Purwo. Danang Parikesit, John Black, Restu Novitarini.2008."Action Research: Transforming Transport Governanve Throug Collaborative Learning". Working Paper 01, Governance Reform Initiative in Transport Sector (GREAT) Project, Center for Transportation and Logistics Studies (PUSTRAL), Gadjah Mada University, Santoso, Purwo,2002. Potret Politik Ilmu-ilmu Sosiat Di Ambang Involusi, [The Portrait of Social Sciences: In the Verge of Crisis], Paper presented at the National Conference, in conjunction with celebration of 47 years of Faculty of Social and Political Science, Gadjah Mada University, 25 September .

Santoso, Purwo, 2010. Defisiensi Teori Pemerintaban: Refleksi Atas Desentralisasi di Indonesia, paper disampaikan dalam Seminar International XI: Dinamika Politik Lokal di Indonesia: Ada Apa dengan 10 Tahun Otonomi Daerah ?, Salatiga, 21-23 July,

Santoso, Purwo dan Kacung Marijan, 2011.“Demokratisasi Indonesia Secara Kontektual, Makalah Kelompok Kerja Demokratisasi”, Disampaikan dalam Konvensi Kampus VII dan Temu Tahunan XIII Forum Rektor Indonesia di Universitas Sriwijaya, Palembang pada tanggal 13-15 Januari 
Santoso, Purwo, Nur Azizah, Nanang Indra K, Joash Tapiheru. E.S., Zarah Ika, 2010."Sinergi Pengembangan Imu Pemerintahan Dengan Pembaharuan Tata Pemerintahan Lokal", Monograph on Politics and Government, Vo. 4 No. 1.

Somantri, Gumilar Rusliwa, 2005. "Membebaskan Ilmu Sosial dari Keterperangkapan Ganda". Jumal Ilmu Sosial dan Ilmu Politik, Vol. 9, No. 2, November.

Verba, Sydney, 1974.Comparative Political Systems, Holbrook Press.

Whitehead, Jack:2009.“Generating Living Theory and Understanding in Action Research Studies, Action Researb, Volume 7(1): 85-99, Los Angeles: SAGE Publications. 